\title{
Directors' human capital, firm strategy, and firm performance
}

\author{
Christophe Volonté • Pascal Gantenbein
}

\begin{abstract}
Ideally, corporations are directed by boards whose directors provide valuable human capital that match the firms' strategy. We investigate how directors' human capital (international experience, industrial know-how, CEO experience, and financial know-how) affects firm performance including the firm's strategy (diversification and internationalization) and how human capital is related to acquisition strategies (non-diversifying and international acquisitions). Our sample consists of 560 firm-year observations in Switzerland. We find empirical evidence that directors' human capital affects firm performance and that this relationship depends on the firm's strategy. Furthermore, human capital is also correlated with acquisition strategy. The study shows that focusing on board independence and compliance issues may be unrewarding in board research and practice.
\end{abstract}

Keywords Corporate governance - Board of directors - Resource dependence theory (RDT) · Agency theory · Human capital · Firm performance

\section{Introduction}

The board of directors assumes the roles of monitoring and advising top management. The first role is advocated by agency theory where the independence of the board from the management is a critical factor (see e.g., Fama and Jensen 1983). The second role is rooted in resource dependence theory (RDT) which highlights the relevance of directors' skills and abilities in response to the firm's external environment (Pfeffer and Salancik 1978). In this function, the board acts as a sparring partner to the management board, sets and supervises the firm's strategy

C. Volonté $(\bowtie) \cdot$ P. Gantenbein

Department of Financial Management, Faculty of Business and Economics, University of Basel,

Peter Merian Weg 6, 4002 Basel, Switzerland

e mail: christophe.volonte@unibas.ch 
and long-term priorities, and provides critical advice to the management (see Lorsch and MacIver 1989). This strategic role is especially relevant in an increasingly competitive world. Pugliese and Wenstøp (2007) and Pugliese et al. (2009) underline the importance of the boards of directors' strategic contribution, while Baysinger and Hoskisson (1990) suggest that board composition and firm strategy are correlated.

Until recently, a majority of studies on board composition has focused on board independence or diversity (see e.g., Hermalin and Weisbach 2003; Farrell and Hersch 2005; Campbell and Vera 2010; Johnson et al. 2013). However, overall these studies yielded only inconclusive results. This might stem from the fact that rather simple attributes of directors may omit other important director characteristics. Arguing from a RDT perspective, Dunn (2012) shows that human capital (education, expertise or business experience; Becker 1964) is relevant for a woman's board appointment (see also Singh et al. 2008; Ahern and Dittmar 2012). Companies increasingly recognize the value of their human capital in corporate governance and as a driver of firm performance (Campbell et al. 2012; Lajili 2014). ${ }^{1}$

Consequently, a number of newer studies investigate the effect of various other director characteristics on firm performance. In an excellent overview, Johnson et al. (2013) analyse empirical board research that appeared in management journals since the 1990s. Increasingly, studies focus on human capital and examine the impact of industry experience, experience as $\mathrm{CEO}$, financial expertise etc. on firm outcomes. In this study, we build on these elements of human capital while in addition, we also control for a variety of other board characteristics such as independence and education.

The provision of human capital is one reason why directors are appointed to the board. However, the board's decision-making capabilities depend on how well the board is composed according to the firm's environment (see e.g., Fama and Jensen 1983; Demb and Neubauer 1992; Stiles and Taylor 1996; Hillman et al. 2000; Hermalin and Weisbach 2003; Adams et al. 2010). Several studies indicate that firm characteristics affect the board of director's composition (see e.g., Anderson et al. 2000; Linck et al. 2008; Lehn et al. 2009) suggesting that it is "an endogenously determined institution" (Hermalin and Weisbach 2003). Directors' human capital should match the challenges of the firm's strategy in order to unfold the board's potential (Hillman et al. 2000; Hillman and Dalziel 2003). Conversely, corporate governance also affects the firm's strategy (see e.g., Amihud and Lev 1999; Hobdari et al. 2011; Cerrato and Piva 2012). Kor and Leblebici (2005) show that the interaction of a firm's human capital and its strategies (such as diversification and internationalization) affects firm performance.

\footnotetext{
${ }^{1}$ The question of personal profile needs also to be addressed, because the performance benefits from career specifics are not directly correlated with director independence or their demographics. As an illustration, the management researchers Hillman et al. (2002) show that "community influentials" are more likely to be females or African American. Similarly, sociologists Zeng and Xie (2004) find evidence that US employees educated abroad earn less than Americans or foreigners educated in the United States. These two examples demonstrate that the omission of certain attributes, such as skill and experience, may cause problems when assessing the aptitude of various profiles for specific posts.
} 
We consider these interdependencies by investigating the conditions under which the board's composition is especially valuable. Specifically, this paper examines the impact of the board of directors' human capital on firm performance taking into account the firm's diversification and internationalization. Diversification and internationalization are two basic elements of firm strategy and significantly affect firm performance (see e.g., Beamish et al. 1989; Chen et al. 2009). In addition, we directly investigate the relationship between human capital and diversification/ internationalization decisions using a firm's mergers and acquisitions (M\&A) strategies.

We employ four director characteristics to describe their human capital: international experience, industrial know-how, CEO experience, and financial know-how. These director characteristics have been brought up as particularly relevant factors in the contribution to a boards' human capital (see e.g., Johnson et al. 2013; Spencer Stuart 2013). We measure diversification and internationalization using the number of a company's business segments and geographic segments (see e.g., Boone et al. 2007; Markarian and Parbonetti 2007; Coles et al. 2008; Linck et al. 2008; Lehn et al. 2009; Knyazeva et al. 2013).

Using hand-collected data from 560 annual reports in Switzerland for the business years 2005, 2007, and 2009, we find statistically significant evidence that directors' human capital affects firm performance (measured by Tobin's Q) and that this relationship depends on the firms' diversification and internationalization. Furthermore, we also provide evidence that the different types of directors' human capital affect a company's acquisition strategy (non-diversifying and international acquisitions). Our regression models include a number of control variables for board, director, and firm characteristics to address omitted variable bias. In addition, we employ Granger causality tests to examine the correlation between human capital and firm performance.

This paper contributes to the RDT and human capital literature in several ways. First of all, we go beyond the independence and diversity criteria in different dimensions and underline the importance of a board of directors' human capital. Secondly, we investigate various aspects of directors' human capital. Among the relatively few studies accounting for human capital, most focus on one single element only (e.g., industrial know-how or financial expertise; see Johnson et al. 2013). Thirdly, research on board of directors has revealed that it is endogenously driven by the firm's environment. We follow several studies that scrutinize the "one size fits all"-approach to corporate governance (see e.g., Boone et al. 2007). We therefore explicitly take into account the firm's diversification and internationalization when investigating the link between directors' human capital and firm performance. Finally, we examine the impact of human capital on strategic decisions, namely the acquisition strategy.

Switzerland offers an interesting research opportunity since most firms successfully compete internationally. The open economy's global orientation and the ever changing globalizing world both require boards composed of educated and experienced members. Swiss boards can be regarded as highly international and professional (see e.g., Heidrick and Struggles 2011). Furthermore, under Swiss law the boards' role is not only to supervise management as it is the case in the German 
two-tier board system, but also to guide the firm and therefore take strategic decisions. Finally, one of the reasons why many empirical studies on board composition are restricted to simple and easily observable director characteristics (e.g., independence or diversity) is the prevalently limited availability of data. In 2002, the introduction of two Swiss standards (the Swiss Code of Best Practice for Corporate Governance and the Directive on Information relating to Corporate Governance) has contributed to improved information disclosure about each director in the annual reports (e.g., by making their curriculum vitae publicly available). This advancement enabled us to obtain the detailed data required for our study which is an exceptional benefit for studies on Swiss corporate governance.

The paper is structured as follows. Section 2 underlines the relevance of directors' human capital in corporate governance. Section 3 develops the hypotheses. Section 4 describes the data and defines the variables. Section 5 presents the empirical analysis and Sect. 6 concludes.

\section{The role of directors' human capital in corporate governance}

The board of directors is vested with the responsibility of making sure that shareholders' money is not wasted. As a result, shareholders ought to have a serious interest in appointing a board composed by well-skilled and experienced directors. Hambrick et al. (2008) point out that "[i]deally, the members of a board of directors are highly qualified to provide professional advise to the managers of the firm" (p. 383). Recent surveys by Withers et al. (2012) and Johnson et al. (2013) show that RDT is fruitful in explaining board outcomes and firm performance. Agency theory's perspective mostly ignores the fact that groups of directors may require different skills in order to execute their duties adequately. Nevertheless, most studies on boards are based on agency theory and focus on board independence or Chief Executive Officer (CEO) duality (see Adams et al. 2010 or Daily et al. 2003 for surveys). However, management researchers argue that agency theory has neither delivered consistent results nor provided a good understanding on the full scope of the board's role (see e.g., Dalton et al. 1998). Even proponents of agency theory, Fama and Jensen (1983), underline the importance of independent directors with specific expertise (e.g., in finance, corporate law or industrial technology) suggesting that independent directors do not all have one and the same purpose on the board. ${ }^{2}$ Human capital may thus be more relevant than independence or demographic attributes in explaining decision-making processes and firm performance (see also Broome et al. 2010 who conducted interviews with directors about the value of diversity). The identification of individual differences in directors'

\footnotetext{
${ }^{2}$ Similarly, Hillman et al. (2000) classify board members skill wise into three categories with specific board roles. The first group, "business experts" have executive experience as CEOs or as officers of large corporations. The second group, "support specialists" provides particular services to the boards; e.g., legal advise or financial expertise. And the final category includes politicians and university professors. This group has no specialized business background, but influences society and opinion making. Such directors are denominated "community influentials" (Baysinger and Butler 1985 apply similar classifications).
} 
human capital, the skills and experiences of individual directors, have also been used in some recent papers which have dealt with more complex characterizations of directors (see e.g., Anderson et al. 2011; Kim and Lim 2010; Johnson et al. 2013). Nevertheless, directors' human capital is not frequently used to describe board composition in academic papers.

In contrast, surveys conducted by consultancy firms frequently mention "hard" and "soft" personal profile factors of directors to be pivotal for board efficiency (see Van den Berghe and Levrau 2004). Such factors include experience, know-how, and education, but also integrity, leadership or credibility (KPMG 2001). Similar reports posit the relevance of expertise such as financial, industrial, leadership or international experience (Spencer Stuart 2013). Corporate leaders themselves precisely specify the profile requirements they expect from their directors. For instance, Airesis, a sporting brands holding, explicitly states in their 2008 annual report that the board must consist of at least one member with board experience in listed companies, one member with a legal background, and one member with financial knowledge. Also shareholders regularly object the lack of specific director characteristics like industrial know-how or financial literacy. For instance, Luqman Arnold from Olivant, a UK investment company, and former CEO of UBS pushed the same UBS in 2007 to appoint more financial specialists on the board. Eventually, UBS appointed David Sidwell former Chief Financial Officer of Morgan Stanley. In addition, various regulations have an influence on the composition of boards, as well. For instance, the US Sarbanes Oxley Act (SOX) of 2002 mandates every board to create audit committees composed of at least one financial expert (see Linck et al. 2009). Thus, academics, consultants, firm leaders, shareholders, and regulators all call for specific expertise on corporate boards.

\section{Hypotheses}

\subsection{Human capital and firm performance}

Empirical evidence substantiates that the concept of RDT is powerful in explaining both board performance and decisions (see Hillman et al. 2009 for a survey). From RDT perspective, board members must provide critical resources, e.g., human capital, in order to advice and counsel the management according to the firms' challenges (see e.g., Pfeffer and Salancik 1978; Hillman et al. 2000, 2008, 2009). ${ }^{3}$ This advisory role of boards and the relevance of expertise has been theoretically and empirically highlighted by several studies (see e.g., Agrawal and Knoeber 2001; Adams and Ferreira 2007; Kor and Misangyi 2008; Walters et al. 2008; Cowen and Marcel 2011). Further studies underline the relevance of directors' human capital (e.g., Hillman et al. 2000, 2002; Certo 2003; Hillman and Dalziel 2003; Peterson and Philpot 2007; Singh et al. 2008; Khanna et al. 2014). As board members have

\footnotetext{
${ }^{3}$ Krause et al. (2013) demarcate the service role of boards which is characterized by providing advice and expertise from the resource dependence role where solely external links to the firm's environment are crucial. We follow, e.g., Hillman and Dalziel (2003) who see both roles as being part of the resource dependence theory.
} 
acquired substantial human capital through their education and experience, their expertise is also one of the main reasons why they are elected on the board in the first place.

Spencer Stuart (2013) sent out a questionnaire to US corporate secretaries asking about what skills they are looking for in their new board members. The respondents' answers shed some light into what kind of human capital is most needed in modern boards: financial expertise $(47 \%)$, international experience $(44 \%)$, specific industry expertise (38\%) and CEO experiences (retired CEOs/COOs [34\%] and active CEOs/COOs [54 \%]). Similarly, the overview of Johnson et al. (2013) shows that characteristics of directors' human capital include industry experience, experience as CEO, venture capital experience, financial expertise, experience with specific activities, human capital heterogeneity, and organizational tenure.

In this study, we focus on four distinct director characteristics that have been argued to be relevant elements of directors' human capital: international experience, industrial know-how, CEO experience, and financial know-how.

\subsubsection{International experience}

Large listed companies most commonly sell their products around the globe. They have often sites in a number of different countries. Thereby, they benefit from increasingly integrated markets and increasing purchasing power of people in emerging markets. In contrast, global diversification also presents significant potential risks such as political, ethical or economical risks. The presence of internationally experienced directors is therefore a must in a globalized world. Oxelheim and Randoy (2003) find significantly higher firm values when AngloSaxon (independent) directors sit on the board of firms in Norway and Sweden. In contrast, Masulis et al. (2012) argue that due to geographic distance (which, for instance, causes opportunity costs of travelling) and different customs, foreign directors may also be less effective monitors. However, also directors who are not foreigners and who live not abroad can possess international experience. Oxelheim et al. (2013) differentiate between foreigners and directors with international experience. They show that while foreigners on boards are rather a consequence of financial internationalization, international experience is a response to foreign sales.

\subsubsection{Industrial know-how}

Industry-specific knowledge helps directing the firm and assessing corporate decisions. Masulis et al. (2013) show that board industrial know-how contributes more to firm performance than board independence. Dass et al. (2014) document that firms benefit from directors of related industries. Also Faleye et al. (2013) and Drobetz et al. (2014) find that directors' industry experience is positively related to firm performance. Finally, Kor and Sundaramurthy (2009) indicate that industryspecific know-how is positively related to sales growth and Kor and Misangyi (2008) show that a shortage of industrial experience of the management engaged in 
young firms can to some extent be compensated by industrial experience of their corporate directors.

\subsubsection{CEO experience}

Directors who worked as CEO know the CEO's job and leadership experience is an important asset of a director (see Lorsch and Maciver 1989; Tian et al. 2011). Fich (2005) provides evidence that stock markets positively react to the appointment of CEOs on boards. Tian et al. (2011) find that directors' CEO experience (and industry know-how) leads to positive stock market reactions when new CEOs are appointed. Fahlenbrach et al. (2011) document the beneficial advisory function of former CEOs on the board of the same firm. In contrast, the study of Fahlenbrach et al. (2010) rejects the claim that stock prices react positively if CEOs are appointed as directors. And Stevenson and Radin (2009) find no significant relationship between CEO experience on the board and firm decisions.

\subsubsection{Financial know-how}

Directors with financial expertise are among the usual candidates for corporate boards. In particular, the introduction of SOX and the requirement of financially literate directors on audit committees have increased the number of financial experts on US boards (see Chhaochharia and Grinstein 2007; Linck et al. 2009). In addition, some countries (especially Germany and Japan) historically have had a significant banking-influence in their corporate governance (see La Porta et al. 1998; Kroszner and Strahan 2001). The prevalence of directors with financial know-how depends on the firm's circumstances (see e.g., Jeanjean and Stolowy 2009; Ramirez 1995). Several empirical studies also have investigated the impact of directors with financial know-how, most notably bankers, on firm policy and on stock prices (see e.g., Byrd and Mizruchi 2005; Güner et al. 2008). Dittmann et al. (2010) show that the presence of bankers on boards of non-financial German companies is negatively related to firm value. DeFond et al. (2005) find that stock prices are documented to react positively if an independent director with financial expertise is appointed to an audit committee of a firm with strong corporate governance.

As the discussion shows, at large all of our four characteristics of human capital have been perceived as key factors of a board. A higher general level of human capital on boards should therefore directly and indirectly (through a higher quality of discussions and decisions) lead to higher firm performance.

Hypothesis 1 Human capital is positively related to firm performance.

3.2 Human capital, firm strategy, and firm performance

Research on corporate boards suggests that the approach of "one size fits all" is misleading, because several factors influence the board's optimal composition (see e.g., Faleye 2007; Boone et al. 2007; Coles et al. 2008; Linck et al. 2008; Lehn et al. 2009). Forbes and Milliken (1999) argue that there are factors such as the firm's size 
or industry affiliation that influence board effectiveness and thus moderate the relationship between board composition and firm performance. For instance, Yermack (1996) argues that boards of more-diversified firms have a higher demand of different expertise.

In addition, according to RDT, board composition should reflect the requirements of a firm's environment such as the firm's strategy. Several studies underline the importance to include the firm's environment when evaluating the board of directors (e.g., Markarian and Parbonetti 2007; Chen et al. 2009). General economic theory suggests that firms would not adapt their corporate governance structure according to their environment if no positive effect on firm performance can be expected.

We therefore argue that the value of directors' specific human capital depends on the firm's strategy. We consider diversification and internationalization which are two basic elements of a firm's strategy and include them as moderating effects in our analysis (see e.g., Beamish et al. 1989; Chen et al. 2009). In addition, both diversification and internationalization are often used as measures to account for a firm's complexity and are therefore commonly included as ordinary control variables (e.g., Markarian and Parbonetti 2007; Kaczmarek and Ruigrok 2013).

\subsubsection{Diversification}

A firm's strategy is often determined by the variety of markets it operates on. Agency theory has been used to explain diversifying acquisitions by self-interested managers. The motives for diversification strategies include the building of empires (Jensen 1986), managerial hubris (i.e., over-optimism) (Roll 1986) or managers' desire to protect their human capital (management entrenchment) (Amihud and Lev 1981; Shleifer and Vishny 1989). Diversifying strategies thus potentially benefit managers and harm shareholders. The resulting diversification discount stems from over-investment in unprofitable industries or subsidization of poorly performing divisions (Lang and Stulz 1994; Berger and Ofek 1995; Aggarwal and Samwick 2003). On the contrary, diversification strategies can create synergies, market power or co-insurance (Eckbo 1983). Co-insurance occurs if cash flows of divisions are not perfectly correlated, therefore reduce risks and facilitate access to credit markets (Lewellen 1971).

\subsubsection{Internationalization}

The increasing integration of world markets presents both an opportunity and risk. Delios and Beamish (1999) find that a firm's grade of internationalization is positively related to firm performance. Accordingly, Hitt et al. (2006) point to the increasing academic research on geographic diversification. For instance, Sanders and Carpenter (1998) reveal that a firm's corporate governance is affected by its internationalization. Managerial motives for internationalization are similar to those of diversification. However, internationalization increases the range of customers for the same products, but rather increases the firm's risk exposure. 
By accounting for the firm's diversification and internationalization, we thereby investigate the channels through which directors' human capital potentially affect firm performance as suggested by Tian et al. (2011).

\subsection{International experience and internalization}

International experience of directors is important in a globalized world where companies often operate in various regions. A firm's ability to adapt their governance structure towards internationalization is a critical competitive advantage (see e.g., Calabrò and Mussolino 2013). Cerrato and Piva (2012) point to the challenges of internationalization such as the involvement with different cultures and laws. They show that a firm's human capital (and the presence of foreign shareholders) positively affects a firm's internationalization. Several other studies indicate that managers' and directors' international experience is positively correlated with a firm's internationalization (see e.g., Tihanyi et al. 2000; Athanassiou and Nigh 2002; Carpenter et al. 2003; Herrmann and Datta 2005; Nielsen 2010). However, the value of international experience is likely to depend on a firm's degree of internationalization. For instance, Masulis et al. (2012) reveal that independent foreign directors provide value in cross-border acquisitions with their respective home country. In contrast, they are negatively related to firm performance if the company has no significant operations in their country. Carpenter et al. (2001) analyse CEOs' international experience in US multinational firms. They provide evidence that the CEOs' international experience is positively related to firm performance especially for firms with significant global exposure. Similarly, Kaczmarek and Ruigrok (2013) show that nationality diversity of top management teams is only beneficial in highly internationalized companies.

Hypothesis 2 The interaction of international experience and internationalization is positively related to firm performance.

\subsection{Industrial know-how and diversification}

Recent research points to the importance of directors' industrial know-how (see e.g., Faleye et al. 2013; Drobetz et al. 2014). Kroll et al. (2008) argue that directors' industrial know-how indicates substantial knowledge about the firm's environment. However, Tian et al. (2011) suggest that industry experience may be less relevant in diversified firms. In other words, diversification decreases the importance of a directors' specific industry know-how.

Hypothesis 3 The interaction of industrial know-how and diversification is negatively related to firm performance.

\subsection{CEO experience and internationalization}

People with CEO experience possess leadership skills required to monitor and advise managements. Sanders and Carpenter (1998) argue that executive experiences exhibit professional expertise which helps firms expanding on international 
markets. Barroso et al. (2011) underline the importance of directors' experience as CEO especially in internationalization strategies. Nevertheless, they find no evidence that CEO experience affects a firm's internationalization. They suggest that directors with CEO experience are aware of risks associated with internationalization and therefore are reluctant to these strategies. Hence, their potentially critical attitude towards internationalization may impede firm performance. However, CEOs today are required to have knowledge about international markets, expansion strategies and the challenges coming from global expansion. Daily et al. (2000) find evidence for a positive effect of a CEO's international experience on firm performance and on a moderating effect of the firm's grade of internationalization. We therefore assume that CEO experience adds particular value if the firm is more active internationally.

Hypothesis 4 The interaction of CEO experience and internationalisation is positively related to firm performance.

\subsection{Financial know-how and diversification}

At least since the introduction of SOX, directors' financial expertise has become an inevitable requirement (see e.g., Linck et al. 2009). Both Güner et al. (2008) and Dittmann et al. (2010) find that directors with financial expertise help to obtain funding from external markets. Also the co-insurance effect of diversified companies facilitates access to credit markets (Ferris et al. 2003). However, diversified firms typically have a functioning corporate center which operates as an internal capital market (see Stein 1997). Internal capital markets therefore potentially reduce the importance of access to external funding and financial expertise on the board. In contrast, higher internal funds may also lead to overinvestments by managers (Jensen 1986; Malmendier and Tate 2005). Financial experts in diversified companies may better be able to direct internal funds to profitable business divisions and more likely to pay out excess cash to shareholders. In this case, over-investment may be less of a concern and firm performance may increase in the presence of financially literate directors.

Hypothesis 5 The interaction of financial know-how and diversification is positively related to firm performance.

\subsection{Human capital and acquisition strategy}

The board of directors sets the firm's strategy and influences acquisition decisions. RDT is increasingly used in explaining the board of directors' contribution to strategy (see Pugliese et al. 2009; Nyberg et al. 2014). Some studies found empirical evidence that directors' human capital influences firm behaviour (see e.g., Dalziel et al. 2011). RDT explains mergers and acquisitions as transactions in order to reduce competition and dependence of transacting partners (see e.g., Pfeffer 1972).

Empirical evidence suggests that director characteristics such as their professional connections (Cai and Sevilir 2012), directors' functional background experiences in finance (Jensen and Zajac 2004), industry experience (Walters 
et al. 2008), experience with acquisitions (McDonald et al. 2008), and their occupational diversity (Hagendorff and Keasey 2012) positively influence stock returns of takeover events. Kroll et al. (2008) find that boards with adequate human capital are positively related to acquisition outcomes. Muehlfeld et al. (2012) show that organizations learn from prior acquisition experiences made in similar contexts, e.g., in non-diversifying (in contrast to diversifying) acquisitions or in international (in contrast to domestic) acquisitions.

International experience on the highest managerial level has been argued to be positively related to internationalization. Cross-border acquisitions are affected by several factors (culture, regulatory environment etc.) that determine integration costs and the takeover's success rate. Knowing the challenges of international markets, internationally experienced directors can therefore be expected to push international acquisitions. In addition, in this way, internationally experienced directors can potentially demonstrate their skills.

Hypothesis 6 International experience is positively related to international acquisitions.

Diversifying acquisitions are perceived as being bad for firm performance. Deutsch (2005) therefore suggests that independent directors are negatively related to diversifying acquisitions. In diversified companies, industrial know-how becomes less important and directors with industrial know-how should therefore drive nondiversifying acquisitions.

Hypothesis 7 Industrial know-how is positively related to non-diversifying acquisitions.

Directors who have CEO experience may demonstrate their leadership skills in cross-border acquisitions. CEO experience therefore should lead to more international acquisitions. In contrast, CEOs have been argued to be rather risk-averse. While diversifying acquisitions reduce a firm's (and manager's) risk exposure by tendency, international acquisitions potentially increase a firm's (and manager's) risk exposure. Thereby, CEO experience of directors can be expected to lead to riskaverse strategies in relation to internationalization (George et al. 2005; Barroso et al. 2011).

Hypothesis 8 CEO experience is negatively related to international acquisitions.

Güner et al. (2008) argue that boards with financial experts undertake worse acquisitions. However, Jensen and Zajac (2004) find that financial know-how on the board is negatively related to acquisition activity. Consequently, if takeover targets are screened more intensively prior to takeover attempts, then they should also better suit the acquiring company. Furthermore, financial know-how is perceived to be positively related to intra-industry acquisitions, because financially literate directors may be aware of the diversification discount (see Lang and Stulz 1994; Berger and Ofek 1995).

Hypothesis 9 Financial know-how is positively related to non-diversifying acquisitions. 
Table 1 Sample selection

\begin{tabular}{llll}
\hline & 2005 & 2007 & 2009 \\
\hline Shares quoted in SPI & 229 & 224 & 221 \\
Investment companies, funds or real estate firms & $(19)$ & $(22)$ & $(19)$ \\
Missing data due to delistings, takeovers or mergers & $(27)$ & $(6)$ & $(0)$ \\
Listed dual class companies & $(5)$ & $(5)$ & $(4)$ \\
Foreign companies & $(0)$ & $(0)$ & $(7)$ \\
Final sample & 178 & 191 & 191 \\
\end{tabular}

\section{Data and methodology}

\subsection{Sample selection}

Our analysis focuses on the Swiss stock market where we target all firms included in the Swiss Performance Index (SPI) in the years 2005, 2007, and 2009. The SPI as the main overall market index comprises most shares that are traded on the SIX Swiss Exchange (SIX). Our sample therefore captures firms of all sizes, ages, and industries, and thereby delivers a high variation in firm characteristics. From all shares quoted in the SPI, we exclude all investment companies or funds, real estate firms and companies with missing or incomplete data (see Table 1). This selection process leads to a sample of 178 firms in 2005, 191 firms in 2007 and 191 firms in 2009 or 560 firm-year observations in total. Due to Switzerland's highly globalized firms and developed capital market, the quality of Switzerland's board of directors can be described as high compared to other continental European countries on average (Heidrick and Struggles 2011). We hand-collected information about 4,021 directorships from 560 annual reports. Furthermore, in some cases, additional information about directors has been obtained from BoardEx and newspapers. Financial data is procured from Thomson Reuters Datastream, while information on diversification and interantionalization is taken from annual reports.

4.2 Dependent variables: firm performance and acquisition strategy

Firm performance in corporate governance studies is commonly measured by means of Tobin's $Q$ (see e.g., Yermack 1996). Like in most empirical studies, we calculate Tobin's $\mathrm{Q}$ as the total assets plus market value of equity minus book value of total equity divided by total assets. The latter is used as an approximation of the replacement value. ${ }^{4}$ The gap between the market value and the book value represents the amount of intangible assets which may, among other factors, mirror

\footnotetext{
${ }^{4}$ The market value of equity is calculated as the average share price 5 days before and 5 days after the last trading day of the year multiplied by the number of outstanding shares. Notably, the study uses all classes of equity, including non listed equity. The market value of non listed equity is estimated according to the firm's listed stock price adjusted for different face values as stipulated by the Swiss tax authorities.
} 
the perceived human capital of the board of directors (see e.g., Kaczmarek et al. 2014).

We use Non-diversifying acquisitions and International acquisitions as proxies for a firm's acquisition strategy. Non-diversifying acquisitions (intra-industry acquisitions in contrast to diversifying acquisitions) measures the proportion of acquisitions where the target is from the same industry as the acquirer. International acquisitions (cross-border acquisitions in contrast to domestic acquisitions) measures the proportion of acquisitions where the target is not from Switzerland. We only consider takeovers that are completed and with a final ownership stake of over $50 \%$. These takeovers occurred in 2005, 2007 or 2009 and thereby at the time when the board was in place.

\subsection{Directors' human capital variables}

We focus on four elements of directors' human capital and use board's averages. International experience indicates the presence of directors who had international exposure, who lived or worked abroad as reported in their résumé or who are foreigners. Foreigners who lived in Switzerland for most of their live do not qualify for international experience. Industrial know-how is proxied by directors who have conducted research in the area or who are working or have been working in the firm's industry sector. CEO experience indicates whether directors have executivelevel experience and leadership experience as CEOs. Financial know-how is allocated to directors with a finance or business background (e.g., business, finance or economics graduates, or bankers, chartered accountants, and controllers).

\subsection{Diversification and internationalization}

Following several studies, we measure a firm's diversification and internationalization using segment information from annual reports. Diversification is the number of business segments while Internationalization represents the number of geographic segments (see e.g., Boone et al. 2007; Markarian and Parbonetti 2007; Linck et al. 2008). The use of numbers of business segments and geographic segments is also motivated by accounting standards (IFRS 8; IAS 14) that require reporting of significant operating segments. Segment information remains fairly unchanged over time and describes the firm's structure in a general way.

\subsection{Board control variables}

We control for a host of board characteristics: Board size is log of the number of board members. Board size has been argued to vary according to firm complexity (see Yermack 1996; Boone et al. 2007). Independence is the fraction of board members who are not present or former executives and have no material business relationships with the firm. Board independence is one of the most widely used variables in board research (see e.g., Boone et al. 2007). Several other aspects of director characteristics may affect firm performance and acquisition strategy. For instance, today's boards are subject more than ever to duties of diligence owing to 
the increasing threat of litigation. Legal compliance issues force modern board members to possess the requisite legal expertise (Linck et al. 2009). The educational background (e.g., lawyers, economists, and engineers or Ivy League education) has also been argued to influence both firm performance and strategies (Dalziel et al. 2011; Rose 2007). We include Legal know-how, MBA degrees (Master of Business Administration), University degrees, Natural sciences graduates, and Technical sciences graduates which all measure the fraction of board members with these characteristics. Additionally, we include Average board tenure and Number of Swiss listed directorships per director on average which are likely to add to a directors' human capital (e.g., by increasing the board's professional relationships and networks, Blair 2011).

\subsection{Control variables}

Board composition and firm performance are affected by a number of firm characteristics (see e.g., Boone et al. 2007; Markarian and Parbonetti 2007; Coles et al. 2008; Linck et al. 2008; Lehn et al. 2009; Yermack 1996). In order to reduce omitted variable bias, we include the following three control variables: Sales growth, Firm age, and Firm size. Sales growth is computed as the geometric mean of yearly sales growth over 4 periods (Black and Khanna 2007). Firm age is log of the number of years since the firm's incorporation plus 1 (Pugliese and Wenstøp 2007). Firm size is log of the firm's total assets (total liabilities plus shareholder's equity) (Yermack 1996). We use logarithms of firm age and firm size to account for skewness. In order to account for industry-specific and year-specific effects, we use industry fixed effects for four sectors in Switzerland (industrial goods and services, personal and household goods, health care, and financial services) and year fixed effects. Table 2 presents the definition of all variables.

\subsection{Summary statistics}

Table 3 shows that about half of all board members on average have specific human capital. $47.5 \%$ provide international experience, $55.6 \%$ possess industrial knowhow, $50.1 \%$ of the directors have experience as CEOs, and $59.1 \%$ of the board members dispose of financial expertise. From 2005 to 2009, international experience, industrial know-how, and financial know-how on the board increased, while CEO experience remained stable. All dependent variables (Tobin's Q, Non-diversifying acquisitions and International acquisitions) indicate a peak in $2007 . .^{5}$

To get a first impression on the board of director's value impact on firm performance, we employ director fixed effects taking account of the fact that some directors appear more than once in the annual sample (see Adams and Ferreira 2008). As Table 4 shows, some directors staff up to 5 directorships at the same time.

\footnotetext{
5 The complete sample is corrected for outliers in Tobin's Q (and Sales growth) with winsorization at the $5 \%$ level in each tail (95 and $5 \%$ ) on the year level (and industry level).
} 
Table 2 Definition of variables

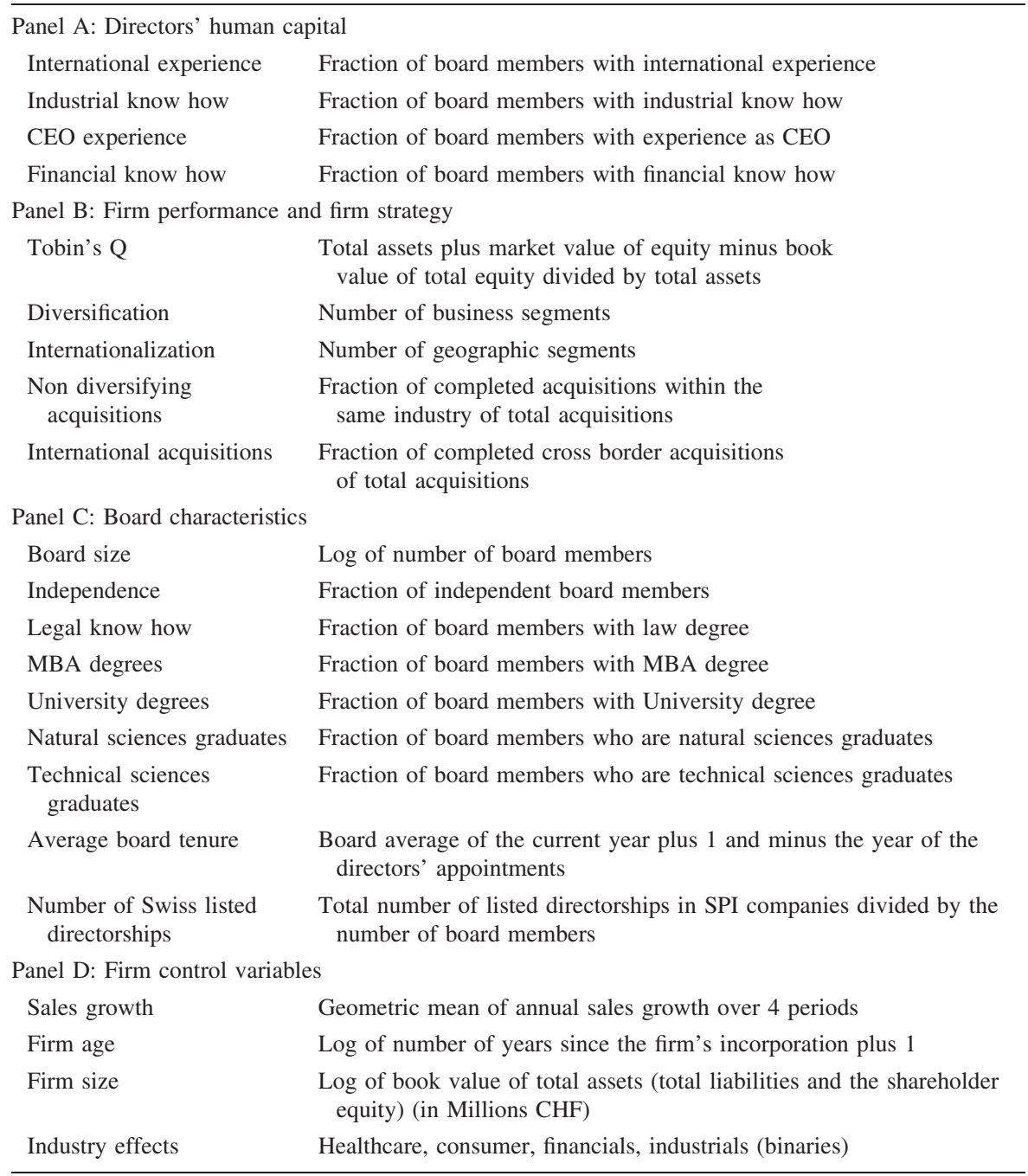

This methodology captures unobservable director-level heterogeneity (e.g., talent) for those directors and facilitates an investigation of whether unexplained or unobserved features drive firm valuation. We therefore use data at the level of individual directorships which contains 4,021 observations. Specifically, we attribute a unique dummy variable to each of the 441 directors who serve on more than one board in a given year. Table 5 shows that director fixed effects significantly improve the explanatory power of the model by around $5 \%$. Therefore, investigating the board of director's specific human capital potentially helps explaining firm outcomes. 
Table 3 Summary statistics of the variables

\begin{tabular}{|c|c|c|c|c|c|c|c|c|}
\hline \multirow{3}{*}{$\begin{array}{l}\text { Years } \\
\text { Number of firms } \\
\text { Variable }\end{array}$} & \multicolumn{5}{|c|}{ 2005, 2007, 2009} & \multirow{3}{*}{$\begin{array}{l}2005 \\
178 \\
\text { Mean }\end{array}$} & \multirow{3}{*}{$\begin{array}{l}2007 \\
191 \\
\text { Mean }\end{array}$} & \multirow{3}{*}{$\begin{array}{l}2009 \\
191 \\
\text { Mean }\end{array}$} \\
\hline & \multicolumn{5}{|l|}{560} & & & \\
\hline & Mean & Median & Min. & Max. & SD & & & \\
\hline \multicolumn{9}{|c|}{ Panel A: Directors' human capital } \\
\hline $\begin{array}{r}\text { International } \\
\text { experience }\end{array}$ & 0.475 & 0.500 & 0.000 & 1.000 & 0.294 & 0.445 & 0.482 & 0.496 \\
\hline Industrial know how & 0.556 & 0.583 & 0.000 & 1.000 & 0.258 & 0.546 & 0.558 & 0.565 \\
\hline CEO experience & 0.501 & 0.500 & 0.000 & 1.000 & 0.218 & 0.501 & 0.504 & 0.499 \\
\hline Financial know how & 0.591 & 0.600 & 0.000 & 1.000 & 0.229 & 0.569 & 0.597 & 0.605 \\
\hline \multicolumn{9}{|c|}{ Panel B: Firm performance and firm strategy } \\
\hline Tobin's Q & 1.625 & 1.289 & 0.845 & 4.366 & 0.828 & 1.614 & 1.776 & 1.485 \\
\hline Diversification & 2.423 & 2.000 & 1.000 & 10.000 & 1.319 & 2.461 & 2.408 & 2.403 \\
\hline Internationalization & 3.312 & 3.000 & 1.000 & 10.000 & 1.723 & 3.303 & 3.304 & 3.330 \\
\hline $\begin{array}{l}\text { Non diversifying } \\
\text { acquisitions }\end{array}$ & 0.197 & 0.000 & 0.000 & 1.000 & 0.388 & 0.180 & 0.221 & 0.189 \\
\hline $\begin{array}{l}\text { International } \\
\text { acquisitions }\end{array}$ & 0.192 & 0.000 & 0.000 & 1.000 & 0.387 & 0.176 & 0.202 & 0.196 \\
\hline \multicolumn{9}{|c|}{ Panel C: Board characteristics } \\
\hline Board size (number) & 7.180 & 7.000 & 3.000 & 15.000 & 2.615 & 7.298 & 7.168 & 7.084 \\
\hline Independence & 0.760 & 0.800 & 0.000 & 1.000 & 0.209 & 0.762 & 0.754 & 0.763 \\
\hline Legal know how & 0.197 & 0.200 & 0.000 & 0.750 & 0.161 & 0.196 & 0.200 & 0.194 \\
\hline MBA degrees & 0.145 & 0.125 & 0.000 & 0.667 & 0.155 & 0.136 & 0.151 & 0.148 \\
\hline University degrees & 0.758 & 0.800 & 0.000 & 1.000 & 0.207 & 0.752 & 0.762 & 0.760 \\
\hline $\begin{array}{l}\text { Natural sciences } \\
\text { graduates }\end{array}$ & 0.093 & 0.000 & 0.000 & 0.889 & 0.156 & 0.093 & 0.095 & 0.091 \\
\hline $\begin{array}{l}\text { Technical sciences } \\
\text { graduates }\end{array}$ & 0.164 & 0.143 & 0.000 & 0.800 & 0.176 & 0.176 & 0.163 & 0.154 \\
\hline Average board tenure & 7.573 & 6.558 & 1.000 & 34.330 & 4.072 & 7.498 & 7.538 & 7.678 \\
\hline $\begin{array}{l}\text { Number of Swiss } \\
\text { listed directorships }\end{array}$ & 0.376 & 0.286 & 0.000 & 1.750 & 0.354 & 0.368 & 0.384 & 0.377 \\
\hline \multicolumn{9}{|c|}{ Panel D: Firm control variables } \\
\hline Sales growth & 0.068 & 0.044 & 0.318 & 1.532 & 0.172 & 0.046 & 0.109 & 0.048 \\
\hline Firm age (years) & 74.4 & 61.0 & 1.0 & 491.0 & 62.5 & 75.9 & 73.4 & 73.9 \\
\hline $\begin{array}{l}\text { Firm size (in Millions } \\
\text { CHF) }\end{array}$ & 27,390 & 8,223 & 0.337 & $2,270,000$ & 170,886 & 29,220 & 29,940 & 23,160 \\
\hline
\end{tabular}

The sample consists of 560 firm year observations in 2005, 2007, and 2009. The table presents mean, median, minimum (Min), and maximum (Max) values as well as standard deviation (SD) for each variable

\subsection{Methodology}

Endogeneity presents a general problem in corporate governance studies. We address endogeneity concerns in several ways. First of all, by studying the effect of directors' human capital, we reduce omitted variable bias on the director-level 
Table 4 Number of SPI directorships by directors

This table reports the absolute number of director characteristics observations

Table 5 Director fixed effects

The table presents regression coefficient estimates of the association of $\mathrm{Q}$ and director fixed effects. The sample consists of 4,021 director observations in 2005,2007 , and 2009. The coefficients are estimated using OLS estimates with White (1980) robust

standard errors. Director Fixed Effects are dummy variables for every director who holds more than one seat in a given year. The table shows estimates, standard errors are reported in parentheses and significance at the 1,5 , and $10 \%$ levels is indicated by $* * *, * *$, and $*$ respectively

\begin{tabular}{lrrrr}
\hline & All & 2005 & 2007 & 2009 \\
\hline Number of directorships & 4,021 & 1,299 & 1,369 & 1,353 \\
Directors with 5 directorships & 4 & 1 & 2 & 1 \\
Directors with 4 directorships & 16 & 6 & 5 & 5 \\
Directors with 3 directorships & 87 & 24 & 32 & 31 \\
Directors with 2 directorships & 334 & 110 & 113 & 111 \\
Directors with 1 directorship & 3,008 & 977 & 1,018 & 1,013 \\
Number of directors & 3,449 & 1,118 & 1,170 & 1,161 \\
\hline
\end{tabular}

\begin{tabular}{lll}
\hline Independent variables & \multicolumn{2}{l}{ Dependent variable: Tobin's Q } \\
\cline { 2 - 3 } & $(\mathrm{I})$ & $(\mathrm{II})$ \\
\hline Intercept) & $1.1010^{* * *}$ & $1.1010^{* * *}$ \\
& $(0.098)$ & $(0.098)$ \\
Sales growth & $0.8238^{* * *}$ & $0.8238^{* * *}$ \\
& $(0.067)$ & $(0.067)$ \\
Firm age & $0.0460^{* * * *}$ & $0.0460^{* * *}$ \\
& $(0.011)$ & $(0.011)$ \\
Firm size & $0.0413^{* * *}$ & $0.0413^{* * *}$ \\
& $(0.006)$ & $(0.006)$ \\
Industry & Included & Included \\
Director fixed effects & Excluded & Included \\
Multiple $R^{2}$ & 0.3552 & 0.4077 \\
Adjusted $R^{2}$ & 0.3541 & 0.3734 \\
$F$ & $315.8^{* * *}$ & $11.89^{* * *}$ \\
Degrees of freedom & 4,013 & 3,800 \\
$F:$ Column I v. Column II: & & $47.2^{* * *}$ \\
\hline
\end{tabular}

which research that solely focusses on board independence or board diversity may face. In contrast, we cannot use firm fixed effects to absorb time-invariant unobserved characteristics on the firm-level, because a board's human capital, the firm's diversification and internationalization are all strategic components which change only very slowly over time. There is insufficient within-firm variation, e.g., the average board tenure is 7.6 years. The use of fixed effects is also inappropriate, because we only have data of 3 periods (2005, 2007, 2009). Secondly, handcollection of data on director characteristics potentially lowers measurement errors. Thirdly, the SPI comprises almost the full array of listed companies in Switzerland and we therefore minimize selection bias in relation to listed Swiss companies. Fourthly, in what concerns reverse causality, we assume that owing to the long-term component of a board's human capital, it may be less of an issue. Firms potentially do rather respond to firm performance by changing their boards' independence or 
diversity. Furthermore, we focus on the question in which circumstances the board's specific human capital creates value and thereby interact board of directors with a firm's long-term strategy. Nevertheless, higher firm performance could increase the ability of a firm to structure its board more adequately. Therefore, we examine reverse causality using Granger causality tests (Granger 1969).

We investigate the effect on firm performance (Tobin's Q) relying on crosssectional (pooled) Ordinary Least Squares (OLS) regressions including several control variables. The models are estimated using a robust covariance matrix according to the method of Driscoll and Kraay (1998). This method consistently estimates standard errors with cross-sectional and serial correlation. Fractional logit regressions for acquisition strategy (Non-diversifying and International acquisitions) are estimated using White (1980) robust standard errors.

\section{Results}

\subsection{Human capital and firm performance}

The board of directors' human capital determines its quality. We therefore directly relate international experience, industrial know-how, CEO experience, and financial know-how to Tobin's Q.

Column I in Table 6 shows that our firm control variables account for $31 \%\left(R^{2}\right)$ of the variation in Tobin's Q. Adding our four variables of interest increases $R^{2}$ by $3.8 \%$. International experience depicts a significant (positive) relationship with Tobin's Q and financial know-how a negative to it (Column II). However, other director characteristics may still be left out and omitted. We thus add another set of board and director characteristics relating to their educational background and experience. The results in Column III show that international experience is still positively related to Tobin's Q, while Industrial know-how, CEO experience and Financial know-how are all negatively related to it. The same results hold including year fixed effects (Column IV). We find statistically significant evidence that directors' human capital affect firm performance. However, we reject Hypothesis 1 that directors' human capital is generally positively related to Tobin's Q.

Since reverse causality is a potential thread, we conduct Granger causality tests and make use of the data's time dimension (see Dittmann et al. 2010). In contrast to standard Granger causality tests, we include lag and lead values of the dependent variable (Tobin's $\mathrm{Q}_{\mathrm{t}-1}$ and Tobin's $\mathrm{Q}_{\mathrm{t}+1}$ ) into the models. ${ }^{6}$ This approach saves enormous data collection efforts especially since corporate governance data is only available for 2005, 2007, and 2009.

Table 7 confirms mostly the results from Table 6. Neither, sample size (Column I), nor the inclusion of a lagged Tobin's $Q$ as an independent variable changes the results (Column II). However, when we regress a lead of Tobin's Q on the independent variables, the results are inconclusive. However, efficient market

\footnotetext{
${ }^{6}$ We collected data for Tobin's Q in 2004, 2006, 2008, and 2010. 23 values of lagged (19) and leaded (4) Tobin's Q are not available which reduces our sample to 537 firm year observations.
} 
Table 6 Directors' human capital and Tobin's Q

\begin{tabular}{|c|c|c|c|c|}
\hline \multirow[t]{2}{*}{ Independent variables } & \multicolumn{4}{|c|}{ Dependent variable: Tobin's Q } \\
\hline & (I) & (II) & (III) & (IV) \\
\hline (Intercept) & $\begin{array}{l}1.41408^{* * * *} \\
(0.103)\end{array}$ & $\begin{array}{l}1.48442 * * * \\
(0.026)\end{array}$ & $\begin{array}{l}1.99711 * * * \\
(0.063)\end{array}$ & $\begin{array}{l}2.02962 * * * \\
(0.108)\end{array}$ \\
\hline Sales growth & $\begin{array}{l}0.98207 * * * \\
(0.065)\end{array}$ & $\begin{array}{l}0.87767 * * * \\
(0.050)\end{array}$ & $\begin{array}{l}0.85042 * * * \\
(0.064)\end{array}$ & $\begin{array}{l}0.76444 * * * \\
(0.062)\end{array}$ \\
\hline Firm age & $\begin{array}{l}0.06912 * * * \\
(0.017)\end{array}$ & $\begin{array}{l}0.02507 \\
(0.017)\end{array}$ & $\begin{array}{l}0.00470 \\
(0.019)\end{array}$ & $\begin{array}{l}0.00648 \\
(0.018)\end{array}$ \\
\hline Firm size & $\begin{array}{l}0.02155 \\
(0.015)\end{array}$ & $\begin{array}{l}0.01006 \\
(0.011)\end{array}$ & $\begin{array}{l}0.00536^{* *} \\
(0.002\end{array}$ & $\begin{array}{l}0.00284 \\
(0.002)\end{array}$ \\
\hline Board size & & & $\begin{array}{l}0.06312 \\
(0.058)\end{array}$ & $\begin{array}{l}0.06799 \\
(0.058)\end{array}$ \\
\hline Independence & & & $\begin{array}{l}0.59400^{* * * *} \\
(0.081)\end{array}$ & $\begin{array}{l}0.58118 * * * \\
(0.076)\end{array}$ \\
\hline Legal know how & & & $\begin{array}{l}0.02736 \\
(0.057)\end{array}$ & $\begin{array}{l}0.00943 \\
(0.057)\end{array}$ \\
\hline MBA degrees & & & $\begin{array}{l}0.80223^{* * * *} \\
(0.117)\end{array}$ & $\begin{array}{l}0.80293 * * * \\
(0.108\end{array}$ \\
\hline University degrees & & & $\begin{array}{l}0.38911 \text { *** } \\
(0.143)\end{array}$ & $\begin{array}{l}0.37119 * * * \\
(0.138)\end{array}$ \\
\hline Natural sciences graduates & & & $\begin{array}{l}0.32337 * * \\
(0.144)\end{array}$ & $\begin{array}{l}0.35096^{* *} \\
(0.136)\end{array}$ \\
\hline Technical sciences graduates & & & $\begin{array}{l}0.05499 \\
(0.085)\end{array}$ & $\begin{array}{l}0.02094 \\
(0.079)\end{array}$ \\
\hline Average board tenure & & & $\begin{array}{l}0.01076^{* * * *} \\
(0.003)\end{array}$ & $\begin{array}{l}0.00998 * * * \\
(0.003)\end{array}$ \\
\hline Number of Swiss listed directorships & & & $\begin{array}{l}0.04199 * * * \\
(0.014)\end{array}$ & $\begin{array}{l}0.04223 * * * \\
(0.016)\end{array}$ \\
\hline International experience & & $\begin{array}{l}0.66818 * * * \\
(0.047)\end{array}$ & $\begin{array}{l}0.63157^{* * * *} \\
(0.032)\end{array}$ & $\begin{array}{l}0.65566^{* * * *} \\
(0.027)\end{array}$ \\
\hline Industrial know how & & $\begin{array}{l}0.06879 \\
(0.044)\end{array}$ & $\begin{array}{l}0.13076 * * * \\
(0.040)\end{array}$ & $\begin{array}{l}0.11589 * * * \\
(0.038)\end{array}$ \\
\hline CEO experience & & $\begin{array}{l}0.02330 \\
(0.054)\end{array}$ & $\begin{array}{l}0.12863^{* * *} * \\
(0.036)\end{array}$ & $\begin{array}{l}0.13780 * * * \\
(0.037)\end{array}$ \\
\hline Financial know how & & $\begin{array}{l}0.15608^{*} \\
(0.084)\end{array}$ & $\begin{array}{l}0.28614^{* *} \\
(0.145\end{array}$ & $\begin{array}{l}0.28964 * * \\
(0.144)\end{array}$ \\
\hline Industry & Included & Included & Included & Included \\
\hline Years & Excluded & Excluded & Excluded & Included \\
\hline Multiple $R^{2}$ & 0.3097 & 0.3479 & 0.3903 & 0.4058 \\
\hline Adjusted $R^{2}$ & 0.3053 & 0.3404 & 0.3757 & 0.3891 \\
\hline
\end{tabular}


Table 6 continued

\begin{tabular}{|c|c|c|c|c|}
\hline \multirow[t]{2}{*}{ Independent variables } & \multicolumn{4}{|c|}{ Dependent variable: Tobin's Q } \\
\hline & (I) & (II) & (III) & (IV) \\
\hline$F$ & $35.38 * * *$ & $26.57 * * *$ & $17.25 * * *$ & $16.67 * * *$ \\
\hline
\end{tabular}

$10 \%$ levels is indicated by $* * *, * *$, and $*$ respectively

Table 7 Robustness: directors' human capital and Tobin's Q

\begin{tabular}{|c|c|c|c|c|c|}
\hline \multirow[t]{3}{*}{ Independent variables } & \multicolumn{5}{|c|}{ Dependent variable } \\
\hline & \multicolumn{2}{|l|}{ Tobin's Q } & \multicolumn{3}{|l|}{ Tobin's $\mathrm{Q}_{\mathrm{t}+1}$} \\
\hline & (I) & (II) & (III) & (IV) & (V) \\
\hline (Intercept) & $\begin{array}{l}2.04290 * * * \\
(0.045)\end{array}$ & $\begin{array}{l}0.75078^{* * *} \\
(0.079)\end{array}$ & $\begin{array}{l}2.08219^{* * *} \\
(0.025)\end{array}$ & $\begin{array}{l}0.53897 * * \\
(0.221)\end{array}$ & $\begin{array}{l}0.38132 * * * \\
(0.099)\end{array}$ \\
\hline Sales growth & $\begin{array}{l}0.73364 * * * \\
(0.067)\end{array}$ & $\begin{array}{l}0.31334 * * * \\
(0.092)\end{array}$ & $\begin{array}{l}0.41374 * * * \\
(0.125)\end{array}$ & $\begin{array}{l}0.14046 * * \\
(0.060)\end{array}$ & \\
\hline Firm age & $\begin{array}{l}0.00753 \\
(0.018)\end{array}$ & $\begin{array}{l}0.00012 \\
(0.013)\end{array}$ & $\begin{array}{l}0.00608 \\
(0.004)\end{array}$ & $\begin{array}{l}0.01177 \\
(0.010)\end{array}$ & \\
\hline Firm size & $\begin{array}{l}0.01081 \\
(0.007)\end{array}$ & $\begin{array}{l}0.01806^{* * * *} \\
(0.004)\end{array}$ & $\begin{array}{l}0.01400 * * * \\
(0.003)\end{array}$ & $\begin{array}{l}0.00584 \\
(0.007)\end{array}$ & \\
\hline Board size & $\begin{array}{l}0.03328 \\
(0.099)\end{array}$ & $\begin{array}{l}0.06331 * * \\
(0.025)\end{array}$ & $\begin{array}{l}0.01500 \\
(0.045)\end{array}$ & $\begin{array}{l}0.01015 \\
(0.035)\end{array}$ & \\
\hline Independence & $\begin{array}{l}0.56983^{* * *} \\
(0.070)\end{array}$ & $\begin{array}{l}0.13810^{*} \\
(0.082)\end{array}$ & $\begin{array}{l}0.45940 * * * \\
(0.038)\end{array}$ & $\begin{array}{l}0.02895 \\
(0.077)\end{array}$ & \\
\hline Legal know how & $\begin{array}{l}0.05686 \\
(0.038)\end{array}$ & $\begin{array}{l}0.20717^{* * * *} \\
(0.080)\end{array}$ & $\begin{array}{l}0.24347^{* * * *} \\
(0.060)\end{array}$ & $\begin{array}{l}0.20052^{* *} \\
(0.078)\end{array}$ & \\
\hline MBA degrees & $\begin{array}{l}0.77331 \text { *** } \\
(0.134)\end{array}$ & $\begin{array}{l}0.10076^{* * * *} \\
(0.021)\end{array}$ & $\begin{array}{l}0.60954 * * * \\
(0.106)\end{array}$ & $\begin{array}{l}0.02537 \\
(0.152)\end{array}$ & \\
\hline University degrees & $\begin{array}{l}0.44521^{* * *} \\
(0.115)\end{array}$ & $\begin{array}{l}0.03785 \\
(0.054)\end{array}$ & $\begin{array}{l}0.57861 * * * \\
(0.039)\end{array}$ & $\begin{array}{l}0.24229 * * * \\
(0.058)\end{array}$ & \\
\hline $\begin{array}{l}\text { Natural sciences } \\
\text { graduates }\end{array}$ & $\begin{array}{l}0.22457^{* *} \\
(0.105)\end{array}$ & $\begin{array}{l}0.12522 * * * \\
(0.024)\end{array}$ & $\begin{array}{l}0.16133^{* * * *} \\
(0.044)\end{array}$ & $\begin{array}{l}0.00832 \\
(0.105)\end{array}$ & \\
\hline $\begin{array}{l}\text { Technical sciences } \\
\text { graduates }\end{array}$ & $\begin{array}{l}0.05210 \\
(0.123)\end{array}$ & $\begin{array}{l}0.17934^{*} \\
(0.099)\end{array}$ & $\begin{array}{l}0.14173 \\
(0.092)\end{array}$ & $\begin{array}{l}0.18109 * * * \\
(0.034)\end{array}$ & \\
\hline Average board tenure & $\begin{array}{l}0.01158^{* * * *} \\
(0.004)\end{array}$ & $\begin{array}{l}0.00417 \\
(0.004)\end{array}$ & $\begin{array}{l}0.01145 \\
(0.011)\end{array}$ & $\begin{array}{c}0.0027 \\
(0.007)\end{array}$ & \\
\hline $\begin{array}{l}\text { Number of Swiss listed } \\
\text { directorships }\end{array}$ & $\begin{array}{l}0.05464 * * \\
(0.021)\end{array}$ & $\begin{array}{l}0.04240 \\
(0.030)\end{array}$ & $\begin{array}{l}0.02175 \\
(0.020)\end{array}$ & $\begin{array}{l}0.01952^{* * * *} \\
(0.004)\end{array}$ & \\
\hline Tobin's Q & & & & $\begin{array}{l}0.75541 * * * \\
(0.116)\end{array}$ & $\begin{array}{l}0.73285^{* * *} \\
(0.115)\end{array}$ \\
\hline
\end{tabular}


Table 7 continued

\begin{tabular}{|c|c|c|c|c|c|}
\hline \multirow[t]{3}{*}{ Independent variables } & \multicolumn{5}{|c|}{ Dependent variable } \\
\hline & \multicolumn{2}{|l|}{ Tobin's Q } & \multicolumn{3}{|l|}{ Tobin's $Q_{t+1}$} \\
\hline & (I) & (II) & (III) & (IV) & (V) \\
\hline Tobin's $\mathrm{Q}_{t}{ }_{1}$ & & $\begin{array}{l}0.90168^{* * *} \\
(0.032)\end{array}$ & & & \\
\hline International experience & $\begin{array}{l}0.63977 * * * \\
(0.028)\end{array}$ & $\begin{array}{l}0.16211^{* * * *} \\
(0.018)\end{array}$ & $\begin{array}{l}0.48513 * * * \\
(0.056)\end{array}$ & $\begin{array}{l}0.00184 \\
(0.062)\end{array}$ & \\
\hline Industrial know how & $\begin{array}{l}0.11623 * * \\
(0.050)\end{array}$ & $\begin{array}{l}0.06434^{* * * *} \\
(0.011)\end{array}$ & $\begin{array}{l}0.07640 * \\
(0.042)\end{array}$ & $\begin{array}{l}0.01140 \\
(0.082)\end{array}$ & \\
\hline CEO experience & $\begin{array}{l}0.12959^{* * * *} \\
(0.022)\end{array}$ & $\begin{array}{l}0.08478^{* * * *} \\
(0.020)\end{array}$ & $\begin{array}{l}0.00130 \\
(0.038)\end{array}$ & $\begin{array}{l}0.09660 * * * \\
(0.037)\end{array}$ & \\
\hline Financial know how & $\begin{array}{l}0.27187 * \\
(0.155)\end{array}$ & $\begin{array}{l}0.10736^{* * *} \\
(0.025)\end{array}$ & $\begin{array}{l}0.01912 \\
(0.175)\end{array}$ & $\begin{array}{l}0.18626 * * * \\
(0.056)\end{array}$ & \\
\hline Industry & Included & Included & Included & Included & Excluded \\
\hline Years & included & Included & Included & Included & Excluded \\
\hline Multiple $R^{2}$ & 0.4133 & 0.8394 & 0.3612 & 0.7336 & 0.5975 \\
\hline Adjusted $R^{2}$ & 0.3956 & 0.8019 & 0.3457 & 0.7008 & 0.5952 \\
\hline$F$ & $16.46^{* * * *}$ & 116.55 & $13.21 * * *$ & $61.42 * * *$ & $794.02 * * *$ \\
\hline
\end{tabular}

This table presents OLS regression coefficient estimates of the association of Tobin's Q and directors' human capital. The sample consists of 537 SPI firm year observations in 2005, 2007, and 2009. Driscoll and Kraay (1998) standard errors are reported in parentheses and significance at the 1, 5, and $10 \%$ levels is indicated by $* * * * *$, and * respectively

hypothesis suggests that markets value the firm (and the quality of the board of directors) today and not with a delay of 1 year. Finally, Wald test $\left(\chi^{2}: 262.18\right)$ suggest that our independent variables besides the dependent variable significantly explain Tobin's Q (Column IV vs. V). Hence, our directors' human capital variables granger cause Tobin's Q.

\subsection{Human capital, firm strategy, and firm performance}

Directors must possess adequate skills that match a firm's strategy. We therefore explicitly take into account diversification and internationalization to assess the impact of directors' human capital on firm performance. In order to evaluate this relationship, we include four interaction terms as moderating factors.

The results in Table 8 indicate that the firm's diversification and internationalization affect the relationship of human capital with firm performance. International experience is especially important for firms with global exposure. Industrial knowhow is negatively related to firm performance as the grade of diversification increases. Financial know-how is positively related to Tobin's Q with increasing diversification. Therefore, we cannot reject Hypothesis 2, 3 and 5. In contrast, CEO experience and Tobin's Q are negatively correlated with increasing internationalization. Hypothesis 4 is therefore rejected. The main effects are similar to the results 
Table 8 Directors' human capital, firm strategy, and Tobin's Q

\begin{tabular}{|c|c|c|}
\hline \multirow[t]{2}{*}{ Independent variables } & \multicolumn{2}{|c|}{ Dependent variable } \\
\hline & $\begin{array}{l}\text { Tobin's Q } \\
\text { (I) }\end{array}$ & $\begin{array}{l}\text { Tobin's } \mathrm{Q}_{\mathrm{t}+1} \\
\text { (II) }\end{array}$ \\
\hline \multirow[t]{2}{*}{ (Intercept) } & $2.00344 * * *$ & $2.00976^{* * *}$ \\
\hline & $(0.113)$ & $(0.041)$ \\
\hline \multirow[t]{2}{*}{ Sales growth } & $0.74779 * * *$ & $0.41125^{* * *}$ \\
\hline & $(0.032)$ & $(0.113)$ \\
\hline \multirow[t]{2}{*}{ Firm age } & 0.00766 & 0.00681 \\
\hline & $(0.019)$ & $(0.007)$ \\
\hline \multirow[t]{2}{*}{ Firm size } & $0.00664 * * *$ & 0.00496 \\
\hline & $(0.002)$ & $(0.004)$ \\
\hline \multirow[t]{2}{*}{ Board size } & 0.07957 & 0.01822 \\
\hline & $(0.055)$ & $(0.040)$ \\
\hline \multirow[t]{2}{*}{ Independence } & $0.56040 * * *$ & $0.42481 * * *$ \\
\hline & $(0.072)$ & $(0.035)$ \\
\hline \multirow[t]{2}{*}{ Legal know how } & 0.03397 & $0.18900 * * *$ \\
\hline & $(0.072)$ & $(0.030)$ \\
\hline \multirow[t]{2}{*}{ MBA degrees } & $0.77656^{* * *}$ & $0.56379 * * *$ \\
\hline & $(0.110)$ & $(0.111)$ \\
\hline \multirow[t]{2}{*}{ University degrees } & $0.28522 *$ & $0.46474 * * *$ \\
\hline & $(0.161)$ & $(0.066)$ \\
\hline \multirow[t]{2}{*}{ Natural sciences graduates } & $0.32799 * * *$ & $0.11627 * *$ \\
\hline & $(0.121)$ & $(0.048)$ \\
\hline \multirow[t]{2}{*}{ Technical sciences graduates } & 0.07536 & $0.22005 * *$ \\
\hline & $(0.090)$ & $(0.101)$ \\
\hline \multirow[t]{2}{*}{ Average board tenure } & $0.00677 * * *$ & 0.00744 \\
\hline & $(0.002)$ & $(0.010)$ \\
\hline \multirow[t]{2}{*}{ Number of Swiss listed directorships } & $0.09128 * * *$ & $0.07918 * * *$ \\
\hline & $(0.031)$ & $(0.022)$ \\
\hline \multirow[t]{2}{*}{ International experience $\times$ internationalization } & $0.10750 * * *$ & $0.15473 * * *$ \\
\hline & $(0.033)$ & $(0.022)$ \\
\hline \multirow[t]{2}{*}{ Industrial know how $\times$ diversification } & $0.11856^{* * * *}$ & $0.14001 * *$ \\
\hline & $(0.042)$ & $(0.057)$ \\
\hline \multirow[t]{2}{*}{ CEO experience $\times$ internationalization } & $0.10363 * * *$ & $0.14367 * * *$ \\
\hline & $(0.032)$ & $(0.008)$ \\
\hline \multirow[t]{2}{*}{ Financial know how $\times$ diversification } & $0.13529 * * *$ & $0.15024 * * *$ \\
\hline & $(0.038)$ & $(0.045)$ \\
\hline \multirow[t]{2}{*}{ International experience } & $0.31479 * * *$ & 0.00793 \\
\hline & $(0.091)$ & $(0.033)$ \\
\hline \multirow[t]{2}{*}{ Industrial know how } & 0.19993 & $0.30657 *$ \\
\hline & $(0.129)$ & $(0.160)$ \\
\hline \multirow[t]{2}{*}{ CEO experience } & 0.17809 & $0.43312 * * *$ \\
\hline & $(0.122)$ & $(0.028)$ \\
\hline
\end{tabular}


Table 8 continued

\begin{tabular}{lll}
\hline Independent variables & \multicolumn{2}{l}{ Dependent variable } \\
\cline { 2 - 3 } & $\begin{array}{l}\text { Tobin's Q } \\
(\mathrm{I})\end{array}$ & $\begin{array}{l}\text { Tobin's } \mathrm{Q}_{\mathrm{t}+1} \\
(\mathrm{II})\end{array}$ \\
\hline Financial know how & $0.62827 * * *$ & 0.38871 \\
Industry & $(0.242)$ & $(0.290)$ \\
Years & Included & Included \\
Number of observations & Included & Included \\
Multiple $R^{2}$ & 560 & 537 \\
Adjusted $R^{2}$ & 0.4148 & 0.3760 \\
$F$ & 0.3948 & 0.3571 \\
\hline
\end{tabular}

This table presents OLS regression coefficient estimates of the association of Tobin's $Q$, directors' human capital, diversification and internationalization. The sample consists of 560 SPI firm year observations in 2005, 2007, and 2009. Driscoll and Kraay (1998) standard errors are reported in parentheses and sig nificance at the 1,5 , and $10 \%$ levels is indicated by $* * *, * *$, and $*$ respectively

in Table 6. Results are identical if Tobin's $\mathrm{Q}_{\mathrm{t}+1}$ is regressed on interaction terms (Column II). Hence, empirical evidence suggests that directors' human capital is a significant determinant of firm performance and that the relationship depends on the firm's diversification and internationalization.

\subsection{Human capital and firm acquisitions}

The board of directors has a strategic role. It sets the firm's strategies and influences acquisition strategy. We therefore estimate the effect of the board of directors' human capital on the proportion of non-diversifying and international acquisitions of a company.

Table 9 Columns I and III provides evidence that a boards' human capital affects a firm's acquisition strategy. This general insight does not change if we control for other variables (Column II and IV). Results suggest that international experience and CEO experience are both significantly positively correlated with international acquisitions. We cannot reject Hypothesis 6, but we reject Hypothesis 8. Against our conjecture, directors' industrial know-how is not significantly correlated with nondiversifying acquisitions. Hypothesis 7 is therefore rejected. In contrast, financial know-how is positively related to it and we thus cannot reject Hypothesis 9.

The results show that while the interaction of international experience and internationalization is positively correlated with firm performance, international experience is also positively related to international acquisitions. This result is consistent and in accordance with the literature. In contrast, the market's perceptions of directors' human capital is not always consistent with the impact of directors' human capital on firm decisions. For instance, while CEO experience is 
Table 9 Fractional logit regressions: acquisitions and directors' human capital

\begin{tabular}{|c|c|c|c|c|}
\hline \multirow[t]{3}{*}{ Independent variables } & \multicolumn{4}{|c|}{ Dependent variable: } \\
\hline & \multicolumn{2}{|c|}{ Non diversifying acquisitions } & \multicolumn{2}{|c|}{ International acquisitions } \\
\hline & (I) & (II) & (III) & (IV) \\
\hline (Intercept) & $\begin{array}{l}0.28544 \\
(0.609)\end{array}$ & $\begin{array}{l}2.56857^{* * * *} \\
(0.789)\end{array}$ & $\begin{array}{l}4.50005^{* * * *} \\
(0.639)\end{array}$ & $\begin{array}{l}5.70731 \text { *** } \\
(0.938)\end{array}$ \\
\hline Sales growth & $\begin{array}{l}1.89372 * * * \\
(0.480)\end{array}$ & $\begin{array}{l}3.47927 * * * \\
(0.575)\end{array}$ & $\begin{array}{l}0.74128^{* *} \\
(0.329)\end{array}$ & $\begin{array}{l}0.50566 \\
(0.498)\end{array}$ \\
\hline Firm age & $\begin{array}{l}0.01456 \\
(0.050)\end{array}$ & $\begin{array}{l}0.20811^{* * * *} \\
(0.067)\end{array}$ & $\begin{array}{l}0.19517 \text { *** } \\
(0.056)\end{array}$ & $\begin{array}{l}0.34757^{* * *} \\
(0.066)\end{array}$ \\
\hline Firm size & $\begin{array}{l}0.05305 \\
(0.033)\end{array}$ & $\begin{array}{l}0.03543 \\
(0.053)\end{array}$ & $\begin{array}{l}0.24750 * * * \\
(0.038)\end{array}$ & $\begin{array}{l}0.47629 * * * \\
(0.067)\end{array}$ \\
\hline Board size & & $\begin{array}{l}0.57592^{*} \\
(0.313)\end{array}$ & & $\begin{array}{l}1.48935 \text { **: } \\
(0.424)\end{array}$ \\
\hline Independence & & $\begin{array}{l}2.50014 * * * \\
(0.341)\end{array}$ & & $\begin{array}{l}1.35315^{* * *} \\
(0.338)\end{array}$ \\
\hline Legal know how & & $\begin{array}{l}2.32300 * * * \\
(0.504)\end{array}$ & & $\begin{array}{l}1.37799^{* * *} \\
(0.630)\end{array}$ \\
\hline MBA degrees & & $\begin{array}{l}1.53334 * * * \\
(0.534)\end{array}$ & & $\begin{array}{l}0.24442 \\
(0.564)\end{array}$ \\
\hline University degrees & & $\begin{array}{l}1.58143^{* * * *} \\
(0.487)\end{array}$ & & $\begin{array}{l}0.95902 \\
(0.653)\end{array}$ \\
\hline Natural sciences graduates & & $\begin{array}{l}3.19512 * * * \\
(0.660)\end{array}$ & & $\begin{array}{l}0.89012 \\
(0.808)\end{array}$ \\
\hline Technical sciences graduates & & $\begin{array}{l}1.43163 * * \\
(0.582)\end{array}$ & & $\begin{array}{l}1.45947 * * \\
(0.612)\end{array}$ \\
\hline Average board tenure & & $\begin{array}{l}0.09758 * * * \\
(0.022)\end{array}$ & & $\begin{array}{l}0.07664 * * * \\
(0.022)\end{array}$ \\
\hline Number of Swiss listed directorships & & $\begin{array}{l}1.25777 * * * \\
(0.176)\end{array}$ & & $\begin{array}{l}1.23711^{* * * *} \\
(0.207)\end{array}$ \\
\hline International experience & $\begin{array}{l}0.35989^{*} \\
(0.211)\end{array}$ & $\begin{array}{l}0.05213 \\
(0.294)\end{array}$ & $\begin{array}{l}1.74421 * * * \\
(0.242)\end{array}$ & $\begin{array}{l}1.54982 * * * \\
(0.312)\end{array}$ \\
\hline Industrial know how & $\begin{array}{l}0.51634 * \\
(0.288)\end{array}$ & $\begin{array}{l}0.36916 \\
(0.369)\end{array}$ & $\begin{array}{l}0.22848 \\
(0.310)\end{array}$ & $\begin{array}{l}0.14794 \\
(0.378)\end{array}$ \\
\hline CEO experience & $\begin{array}{l}1.41499 * * * \\
(0.288)\end{array}$ & $\begin{array}{l}1.07214 * * * \\
(0.352)\end{array}$ & $\begin{array}{l}2.32494 * * * \\
(0.326)\end{array}$ & $\begin{array}{l}2.16267 * * * \\
(0.395)\end{array}$ \\
\hline Financial know how & $\begin{array}{l}0.45843^{*} \\
(0.239)\end{array}$ & $\begin{array}{l}0.68430 * \\
(0.407)\end{array}$ & $\begin{array}{l}1.39190^{* * * *} \\
(0.291)\end{array}$ & $\begin{array}{l}1.81554 * * * \\
(0.414)\end{array}$ \\
\hline Industry & Included & Included & Included & Included \\
\hline Year & Included & Included & Included & Included \\
\hline
\end{tabular}


Table 9 continued

\begin{tabular}{|c|c|c|c|c|}
\hline \multirow[t]{3}{*}{ Independent variables } & \multicolumn{4}{|c|}{ Dependent variable: } \\
\hline & \multicolumn{2}{|c|}{ Non diversifying acquisitions } & \multicolumn{2}{|c|}{ International acquisitions } \\
\hline & (I) & (II) & (III) & (IV) \\
\hline McFadden & 0.1003 & 0.1760 & 0.2450 & 0.3050 \\
\hline
\end{tabular}

The table presents Fractional Logit regression coefficient estimates for acquisitions. The sample consists of 560 SPI firm years observations in 2005, 2007, and 2009. White (1980) standard errors are reported in parentheses, and significance at the 1,5 , and $10 \%$ levels is indicated by ***, **, and *, respectively

negatively related with firm performance as internationalization increases, CEO experience is positively related to international acquisitions and thus pushing the firm's internationalization even further. Financial expertise is more valuable in diversified companies, while it is positively related to non-diversifying acquisitions.

\section{Conclusions}

The development of corporate governance in the last years shifted the board's tasks toward compliance and risk management issues, however, the board is also responsible to direct the company and determine its strategic goals. The latter role is stressed by RDT. The board not only acts as monitor of managers on behalf of the shareholders, but has also responsibilities in strategic management. The study emphasizes the relevance of RDT for explaining the effect of board composition on firm performance and firm decisions.

Johnson et al. (2013) suggest that studies should improve the measurement of board characteristics, e.g., human capital, the theory behind these characteristics and should use consistent measures of board characteristics. In this study, we use four elements of directors' human capital as suggested by theory and practice: international experience, industrial know-how, CEO experience, and financial know-how. Directors' human capital is one reason why they are appointed to the board in the first place and it should ideally match the firm's needs. We therefore argue that the relationship between the board of directors and firm performance is likely to be affected by (1) the directors' human capital and by (2) the firm's strategy that specifies the directors' qualities and abilities needed on the board. Particularly, we suppose that the board-performance relationship varies depending on the firm's diversification and internationalization. Furthermore, (3) directors' human capital is likely to influence acquisition strategy.

Empirical evidence indicates that the relationship between directors' human capital and firm performance is moderated by the firm's strategy. The inclusion of interaction terms shows that human capital is relevant and that its value depends on the firm's diversification and internationalization. Hence, the value of a board's composition affects firm performance through specific channels or strategies. We underline this perception by showing that directors' human capital actually also influences acquisition strategies. 
As expected, empirical evidence suggests that industrial know-how is negatively correlated with firm performance in diversified firms. The results show also other interesting relationships. For instance, while international experience is positively related to firm performance as the grade of internationalization increases, international experience is also positively related to international acquisitions further pushing internationalization. In contrast, CEO experience is negatively related to firm performance in internationalized companies. However, CEO experience is positively related to international acquisitions. Both results are contrary to our hypotheses and may suggest that also CEOs may overestimate their ability in international expansion strategies.

Overall, our study demonstrates that the claim of "one size fits all" often implicitly stated by regulators and advisors is misleading in corporate governance. The firm's environment must be taken into account when the board is evaluated. In addition, instead of focusing on board independence, corporate governance experts should also explicitly consider directors' experience and education. Board nomination committees, recruiters, proxy advisors, investors such as pension funds, and regulators should consider directors' human capital when appointing or evaluating board members.

However, this study is not without limitations. The definition of human capital requires further examination. The interdependence between directors' human capital and firm strategy needs more detailed empirical investigations. In addition, the relationship between board composition and firm performance is complex. A longer time period could help understanding the dynamism of board composition, the firm's environment, and their relationship with board performance and decisions. Our study uses data of listed companies in Switzerland. Therefore, the results may be unique to the Swiss context and may not apply for other institutional environments.

Corporate governance research often aims to identify the optimal board composition. We suggest that future research should further focus on understanding why and how boards affect firm performance and strategies. Researchers should therefore try to open this "black box" in order to evaluate which director characteristics (e.g., experience in emerging markets) through which channels (e.g., strong corporate expansion) affect firm performance.

Acknowledgments The authors acknowledge the research grant by the Förderverein WWZ (B 119). We thank three anonymous referees for their helpful comments and Hermione Miller Moser for her editorial assistance. This paper is based on Chapter 6 of the Ph.D thesis by Christophe Volonté: "Corporate Governance in Switzerland", University of Basel, 2011. Christophe Volonté thanks the University of Manchester for providing him with access to BoardEx during his research stay at the Manchester Business School.

\section{References}

Adams, R. B., \& Ferreira, D. (2007). A theory of friendly boards. The Journal of Finance, 62(1), 217250.

Adams, R. B., \& Ferreira, D. (2008). Do directors perform for pay? Journal of Accounting and Economics, 46(1), 154171. 
Adams, R. B., Hermalin, B. E., \& Weisbach, M. S. (2010). The role of boards of directors in corporate governance: A conceptual framework and survey. Journal of Economic Literature, 48(1), 58107.

Aggarwal, R. K., \& Samwick, A. A. (2003). Why do managers diversify their firms? Agency reconsidered. Journal of Finance, 58(1), 71118.

Agrawal, A., \& Knoeber, C. R. (2001). Do some outside directors play a political role? Journal of Law and Economics, 44(1), 179198.

Ahern, K. R., \& Dittmar, A. K. (2012). The changing of the boards: The impact on firm valuation of mandated female board representation. The Quarterly Journal of Economics, 127(1), 137197.

Amihud, Y., \& Lev, B. (1981). Risk reduction as a managerial motive for conglomerate mergers. The Bell Journal of Economics, 12(2), 605617.

Amihud, Y., \& Lev, B. (1999). Does corporate ownership structure affect its strategy towards diversification? Strategic Management Journal, 20(11), 10631069.

Anderson, R. C., Bates, T. W., Bizjak, J. M., \& Lemmon, M. L. (2000). Corporate governance and firm diversification. Financial Management, 29(1), 522.

Anderson, R. C., Reeb, D. M., Upadhyay, A., \& Zhao, W. (2011). The economics of director heterogeneity. Financial Management, 40(1), 538.

Athanassiou, N., \& Nigh, D. (2002). The impact of the top management team's international business experience on the firm's internationalization: Social networks at work. Management International Review, 42(2), 157181.

Barroso, C., Villegas, M. M., \& Pérez Calero, L. (2011). Board influence on a firm's internationalization. Corporate Governance: An International Review, 19(4), 351367.

Baysinger, B. D., \& Butler, H. N. (1985). Corporate governance and the board of directors: Performance effects of changes in board composition. Journal of Law Economics and Organization, 1(1), 101124.

Baysinger, B. D., \& Hoskisson, R. E. (1990). The composition of boards of directors and strategic control: Effects on corporate strategy. Academy of Management Review, 15(1), 7287.

Beamish, P. W., Dacosta, R. C., \& Geringer, J. M. (1989). Diversification strategy and international ization: Implications for MNE performance. Strategic Management Journal, 10(2), 109119.

Becker, G. (1964). Human capital. New York: Columbia University Press.

Berger, P. G., \& Ofek, E. (1995). Diversification's effect on firm value. Journal of Financial Economics, 37(1), 3965.

Black, B. S., \& Khanna, V. S. (2007). Can corporate governance reforms increase firm market values? Event study evidence from India. Journal of Empirical Legal Studies, 4(4), 749796.

Blair, M. (2011). An economic perspective on the notion of human capital. In A. Burton Jones \& J. C. Spender (Eds.), The Oxford handbook of human capital (pp. 49 70). Oxford: Oxford University Press.

Boone, A. L., Field, L. C., Karpoff, J. M., \& Raheja, C. G. (2007). The determinants of corporate board size and composition: An empirical analysis. Journal of Financial Economics, 85(1), 66101.

Broome, L. L., Conley, J. M., \& Krawiec, K. D. (2010). Dangerous categories: Narratives of corporate board diversity. NCL Review, 89, 759804.

Byrd, D. T., \& Mizruchi, M. S. (2005). Bankers on the board and the debt ratio of firms. Journal of Corporate Finance, 11(1 2), 129173.

Cai, Y., \& Sevilir, M. (2012). Board connections and M\&A transactions. Journal of Financial Economics, 103(2), 327349.

Calabrò, A., \& Mussolino, D. (2013). How do boards of directors contribute to family SME export intensity? The role of formal and informal governance mechanisms. Journal of Management and Governance, 17(2), 363403.

Campbell, B. A., Coff, R. W., \& Kryscynski, D. (2012). Rethinking sustained competitive advantage from human capital. Academy of Management Review, 37, 376395.

Campbell, K., \& Vera, A. M. (2010). Female board appointments and firm valuation: Short and long term effects. Journal of Management and Governance, 14(1), 3759.

Carpenter, M. A., Pollock, T. G., \& Leary, M. M. (2003). Testing a model of reasoned risk taking: Governance, the experience of principals and agents, and global strategy in high technology IPO firms. Strategic Management Journal, 24(9), 803820.

Carpenter, M. A., Sanders, W. G., \& Gregersen, H. B. (2001). Bundling human capital with organizational context: The impact of international assignment experience on multinational firm performance and CEO pay. Academy of Management Journal, 44(3), 493511. 
Cerrato, D., \& Piva, M. (2012). The internationalization of small and medium sized enterprises: The effect of family management, human capital and foreign ownership. Journal of Management and Governance, 16(4), 617644.

Certo, S. T. (2003). Influencing initial public offering investors with prestige: Signaling with board structures. Academy of Management Review, 28(3), 432446.

Chen, R., Dyball, M. C., \& Wright, S. (2009). The link between board composition and corporate diversification in Australian corporations. Corporate Governance: An International Review, 17(2), 208223.

Chhaochharia, V., \& Grinstein, Y. (2007). The changing structure of U.S. corporate boards: 19972003. Corporate Governance: An International Review, 15(6), 12151223.

Coles, J. L., Daniel, N. D., \& Naveen, L. (2008). Boards: Does one size fit all? Journal of Financial Economics, 87(2), 329356.

Cowen, A. P., \& Marcel, J. J. (2011). Damaged goods: Board decisions to dismiss reputationally compromised directors. Academy of Management Journal, 54(3), 509527.

Daily, C. M., Certo, S. T., \& Dalton, D. R. (2000). International experience in the executive suite: The path to prosperity? Strategic Management Journal, 21(4), 515523.

Daily, C. M., Dalton, D. R., \& Cannella, A. A. (2003). Corporate governance: Decades of dialogue and data. Academy of Management Review, 28(3), 371382.

Dalton, D. R., Daily, C. M., Ellstrand, A. E., \& Johnson, J. L. (1998). Meta analytic reviews of board composition, leadership structure, and financial performance. Strategic Management Journal, 19(3), 269290.

Dalziel, T., Gentry, R. J., \& Bowerman, M. (2011). An integrated agency Resource dependence view of the influence of directors' human and relational capital on firms' R\&D spending. Journal of Management Studies, 48(6), 12171242.

Dass, N., Kini, O., Nanda, V., Onal, B., \& Wang, J. (2014). Board expertise: Do directors from related industries help bridge the information gap? Review of Financial Studies, 27(5), 15331592.

DeFond, M. L., Hann, R. N., \& Hu, X. (2005). Does the market value financial expertise on audit committees of boards of directors? Journal of Accounting Research, 43(2), 153193.

Delios, A., \& Beamish, P. W. (1999). Geographic scope, product diversification, and the corporate performance of Japanese firms. Strategic Management Journal, 20(8), 711727.

Demb, A., \& Neubauer, F. (1992). The corporate board: Confronting the paradoxes. Long Range Planning, 25(3), 920.

Deutsch, Y. (2005). The impact of board composition on firms' critical decisions: A meta analytic review. Journal of Management, 31(3), 424444.

Dittmann, I., Maug, E. G., \& Schneider, C. (2010). Bankers on the boards of German firms: What they do, what they are worth, and why they are (still) there. Review of Finance, 14(1), 3571.

Driscoll, J. C., \& Kraay, A. C. (1998). Consistent covariance matrix estimation with spatially dependent panel data. Review of Economics and Statistics, 80(4), 549560.

Drobetz, W., Von Meyerinck, Oesch, D., \& Schmid, M. (2014). Is board industry experience a corporate governance mechanism? University of St.Gallen, School of Finance Research Paper No. 2014/01.

Dunn, P. (2012). Breaking the boardroom gender barrier: The human capital of female corporate directors. Journal of Management and Governance, 16(4), 557570.

Eckbo, B. E. (1983). Horizontal mergers, collusion, and stockholder wealth. Journal of Financial Economics, 11(1), 241273.

Fahlenbrach, R., Low, A., \& Stulz, R. M. (2010). Why do firms appoint CEOs as outside directors? Journal of Financial Economics, 97(1), 1232.

Fahlenbrach, R., Minton, B. A., \& Pan, C. H. (2011). Former CEO directors: Lingering CEOs or valuable resources? Review of Financial Studies, 24(10), 34863518.

Faleye, O. (2007). Does one hat fit all? The case of corporate leadership structure. Journal of Management and Governance, 11(3), 239259.

Faleye, O., Hoitash, R., \& Hoitash, U. (2013). Industry expertise on corporate boards. Northeastern U. D'Amore McKim School of Business Research Paper No. 201304.

Fama, E. F., \& Jensen, M. C. (1983). Separation of ownership and control. The Journal of Law and Economics, 26(2), 301325.

Farrell, K., \& Hersch, P. (2005). Additions to corporate boards: The effect of gender. Journal of Corporate Finance, 11(1), 85106.

Ferris, S. P., Kim, K. A., \& Kitsabunnarat, P. (2003). The costs (and benefits?) of diversified business groups: The case of Korean chaebols. Journal of Banking \& Finance, 27(2), 251273. 
Fich, E. M. (2005). Are some outside directors better than others? Evidence from director appointments by Fortune 1000 firms. The Journal of Business, 78(5), 19431972.

Forbes, D. P., \& Milliken, F. J. (1999). Cognition and corporate governance: Understanding boards of directors as strategic decision making groups. Academy of Management Review, 24(3), 489505.

George, G., Wiklund, J., \& Zahra, S. A. (2005). Ownership and the internationalization of small firms. Journal of Management, 31(2), 210233.

Granger, C. W. J. (1969). Investigating causal relations by econometric models and cross spectral methods. Econometrica, 37(3), 424438.

Güner, A. B., Malmendier, U., \& Tate, G. (2008). Financial expertise of directors. Journal of Financial Economics, 88(2), 323354.

Hagendorff, J., \& Keasey, K. (2012). The value of board diversity in banking: Evidence from the market for corporate control. The European Journal of Finance, 18(1), 4158.

Hambrick, D. C., Werder, A., \& Zajac, E. J. (2008). New directions in corporate governance research. Organization Science, 19(3), 381385.

Heidrick \& Struggles (2011). Challenging board performance: European corporate governance report 2011. Paris: Heidrick \& Struggles International, Inc.

Hermalin, B. E., \& Weisbach, M. S. (2003). Boards of directors as an endogenously determined institution: A survey of the economic literature. Economic Policy Review, 9(1), 726.

Herrmann, P., \& Datta, D. K. (2005). Relationships between top management team characteristics and international diversification: An empirical investigation. British Journal of Management, 16(1), 6978.

Hillman, A. J., Cannella, A. A., \& Harris, I. C. (2002). Women and racial minorities in the boardroom: How do directors differ? Journal of Management, 28(6), 747763.

Hillman, A. J., Cannella, A. A., \& Paetzold, R. L. (2000). The resource dependence role of corporate directors: Strategic adaptation of board composition in response to environmental change. Journal of Management Studies, 37(2), 235256.

Hillman, A. J., \& Dalziel, T. (2003). Boards of directors and firm performance: Integrating agency and resource dependence perspectives. The Academy of Management Review, 28(3), 383396.

Hillman, A. J., Nicholson, G., \& Shropshire, C. (2008). Directors' multiple identities, identification, and board monitoring and resource provision. Organization Science, 19(3), 441456.

Hillman, A. J., Withers, M. C., \& Collins, B. J. (2009). Resource dependence theory: A review. Journal of Management, 35(6), 14041427.

Hobdari, B., Gregoric, A., \& Sinani, E. (2011). The role of firm ownership on internationalization: Evidence from two transition economies. Journal of Management and Governance, 15(3), 393413.

Jeanjean, T., \& Stolowy, H. (2009). Determinants of board members' financial expertise Empirical evidence from France. The International Journal of Accounting, 44(4), 378402.

Jensen, M. C. (1986). Agency costs of free cash flow, corporate finance, and takeovers. American Economic Review, 76(2), 323329.

Jensen, M., \& Zajac, E. J. (2004). Corporate elites and corporate strategy: How demographic preferences and structural position shape the scope of the firm. Strategic Management Journal, 25(6), 507524.

Johnson, S. G., Schnatterly, K., \& Hill, A. D. (2013). Board composition beyond independence social capital, human capital, and demographics. Journal of Management, 39(1), 232262.

Kaczmarek, S., Kimino, S., \& Pye, A. (2014). Interlocking directorships and firm performance in highly regulated sectors: The moderating impact of board diversity. Journal of Management and Governance, 18(2), 347372.

Kaczmarek, S., \& Ruigrok, W. (2013). In at the deep end of firm internationalization. Management International Review, 53(4), 513534.

Khanna, P., Jones, C. D., \& Boivie, S. (2014). Director human capital, information processing demands, and board effectiveness. Journal of Management, 40(2), 557585.

Kim, H., \& Lim, C. (2010). Diversity, outside directors and firm valuation: Korean evidence. Journal of Business Research, 63(3), 284291.

Knyazeva, A., Knyazeva, D., \& Masulis, R. W. (2013). The supply of corporate directors and board independence. Review of Financial Studies, 26(6), 15611605.

Kor, Y. Y., \& Leblebici, H. (2005). How do interdependencies among human capital deployment, development, and diversification strategies affect firms' financial performance? Strategic Manage ment Journal, 26(10), 967985.

Kor, Y. Y., \& Misangyi, V. F. (2008). Outside directors' industry specific experience and firms' liability of newness. Strategic Management Journal, 29(12), 13451355. 
Kor, Y. Y., \& Sundaramurthy, C. (2009). Experience based human capital and social capital of outside directors. Journal of Management, 35(4), 9811006.

KPMG. (2001). Corporate Governance in der Schweiz: Verwaltungsrat zwischen Verantwortung und Haftung. Zürich: KPMG Fides Management AG.

Krause, R., Semadeni, M., \& Cannella, A. A. (2013). External COO/presidents as expert directors: A new look at the service role of boards. Strategic Management Journal, 34(13), 16281641.

Kroll, M., Walters, B. A., \& Wright, P. (2008). Board vigilance, director experience, and corporate outcomes. Strategic Management Journal, 29(4), 363382.

Kroszner, R. S., \& Strahan, P. E. (2001). Bankers on boards: Monitoring, conflicts of interest, and lender liability. Journal of Financial Economics, 62(3), 415452.

La Porta, R., Lopez de Silanes, F., Shleifer, A., \& Vishny, R. (1998). Law and finance. The Journal of Political Economy, 106(6), 11131155.

Lajili, K. (2014). Embedding human capital into governance design: A conceptual framework. Journal of Management and Governance, 18(3), 122.

Lang, L. H., \& Stulz, R. M. (1994). Tobin's q, corporate diversification, and firm performance. Journal of Political Economy, 102(6), 12481280.

Lehn, K. M., Patro, S., \& Zhao, M. (2009). Determinants of the size and composition of US corporate boards: 1935 2000. Financial Management, 38(4), 747780.

Lewellen, W. G. (1971). A pure financial rationale for the conglomerate merger. The Journal of Finance, 26(2), 521537.

Linck, J. S., Netter, J. M., \& Yang, T. (2008). The determinants of board structure. Journal of Financial Economics, 87(2), 308328.

Linck, J. S., Netter, J. M., \& Yang, T. (2009). The effects and unintended consequences of the Sarbanes Oxley act on the supply and demand for directors. Review of Financial Studies, 22(8), 32873328.

Lorsch, J. W., \& MacIver, E. (1989). Pawns or potentates: The reality of America's corporate boards. Boston, MA: Harvard Business School Press.

Malmendier, U., \& Tate, G. (2005). CEO overconfidence and corporate investment. The Journal of Finance, 60(6), 26612700.

Markarian, G., \& Parbonetti, A. (2007). Firm complexity and board of director composition. Corporate Governance: An International Review, 15(6), 12241243.

Masulis, R. W., Ruzzier, C. A., Xiao, S., \& Zhao, S. (2013). Do independent expert directors matter? Working Paper, University of New South Wales.

Masulis, R. W., Wang, C., \& Xie, F. (2012). Globalizing the boardroom The effects of foreign directors on corporate governance and firm performance. Journal of Accounting and Economics, 53(3), 527554 .

McDonald, M. L., Westphal, J. D., \& Graebner, M. E. (2008). What do they know? The effects of outside director acquisition experience on firm acquisition performance. Strategic Management Journal, 29(11), 11551177.

Muehlfeld, K., Rao Sahib, P., \& Van Witteloostuijn, A. (2012). A contextual theory of organizational learning from failures and successes: A study of acquisition completion in the global newspaper industry, 1981 2008. Strategic Management Journal, 33(8), 938964.

Nielsen, S. (2010). Top management team internationalization and firm performance. Management International Review, 50(2), 185206.

Nyberg, A. J., Moliterno, T. P., Hale, D., Hale, D., \& Lepak, D. P. (2014). Resource based perspective on unit level human capital: A review and integration. Journal of Management, 40(1), 316346.

Oxelheim, L., Gregoric, A., Randoy, T., \& Thomsen, S. (2013). On the internationalization of corporate boards: The case of Nordic firms. Journal of International Business Studies, 44(3), 173194.

Oxelheim, L., \& Randoy, T. (2003). The impact of foreign board membership on firm value. Journal of Banking \& Finance, 27(12), 23692392.

Peterson, C. A., \& Philpot, J. (2007). Women's roles on US Fortune 500 boards: Director expertise and committee memberships. Journal of Business Ethics, 72(2), 177196.

Pfeffer, J. (1972). Merger as a response to organizational interdependence. Administrative Science Quarterly, 17, 382394.

Pfeffer, J., \& Salancik, G. R. (1978). The external control of organizations: A resource dependence perspective. New York: Harper \& Row.

Pugliese, A., Bezemer, P. J., Zattoni, A., Huse, M., Van den Bosch, F. A. J., \& Volberda, H. W. (2009). Boards of directors' contribution to strategy: A literature review and research agenda. Corporate Governance: An International Review, 17(3), 292306. 
Pugliese, A., \& Wenstøp, P. Z. (2007). Board members' contribution to strategic decision making in small firms. Journal of Management and Governance, 11(4), 383404.

Ramirez, C. D. (1995). Did JP Morgan's men add liquidity? Corporate investment, cash flow, and financial structure at the turn of the twentieth century. Journal of Finance, 50(2), 661678.

Roll, R. (1986). The hubris hypothesis of corporate takeovers. Journal of Business, 59(2), 197216.

Rose, C. (2007). Does female board representation influence firm performance? The Danish evidence. Corporate Governance: An International Review, 15(2), 404413.

Sanders, W. G., \& Carpenter, M. A. (1998). Internationalization and firm governance: The roles of CEO compensation, top team composition, and board structure. Academy of Management Journal, 41(2), 158178.

Shleifer, A., \& Vishny, R. W. (1989). Management entrenchment: The case of manager specific investments. Journal of Financial Economics, 25(1), 123139.

Singh, V., Terjesen, S., \& Vinnicombe, S. (2008). Newly appointed directors in the boardroom: How do women and men differ? European Management Journal, 26(1), 4858.

Spencer Stuart (2013). Spencer Stuart board index (28th ed.). Downloaded from www.spencerstuart.com.

Stein, J. (1997). Internal capital markets and competition for corporate resources. Journal of Finance, 52(1), 111133.

Stevenson, W. B., \& Radin, R. F. (2009). Social capital and social influence on the board of directors. Journal of Management Studies, 46(1), 1644.

Stiles, P., \& Taylor, B. (1996). The strategic role of the board. Corporate Governance: An International Review, 4(1), 310 .

Tian, J. J., Haleblian, J. J., \& Rajagopalan, N. (2011). The effects of board human and social capital on investor reactions to new CEO selection. Strategic Management Journal, 32(7), 731747.

Tihanyi, L., Ellstrand, A. E., Daily, C. M., \& Dalton, D. R. (2000). Composition of the top management team and firm international diversification. Journal of Management, 26(6), 11571177.

Van den Berghe, L. A., \& Levrau, A. (2004). Evaluating boards of directors: What constitutes a good corporate board? Corporate Governance: An International Review, 12(4), 461478.

Walters, B. A., Kroll, M., \& Wright, P. (2008). Board vigilance, director experience, and corporate outcomes. Strategic Management Journal, 29(4), 363382.

White, H. (1980). A heteroskedasticity consistent covariance matrix estimator and a direct test for heteroskedasticity. Econometrica: Journal of the Econometric Society, 48(4), 817838.

Withers, M. C., Hillman, A. J., \& Cannella, A. A. (2012). A multidisciplinary review of the director selection literature. Journal of Management, 38(1), 243277.

Yermack, D. (1996). Higher market valuation of companies with a small board of directors. Journal of Financial Economics, 40(2), 185211.

Zeng, Z., \& Xie, Y. (2004). Asian Americans' earnings disadvantage reexamined: The role of place of education. The American Journal of Sociology, 109(5), 10751108.

Dr. Christophe Volonté is postdoctoral researcher at the Department of Financial Management at University of Basel. Volonté has been visiting researcher at Simon Fraser University, University of Technology, Sydney, the Manchester Business School, and the Copenhagen Business School. His research interests are in the areas of corporate governance, corporate finance, venture capital, and law and finance. He has published in academic journals such as International Review of Law and Economics and Management International Review.

Prof. Dr. Pascal Gantenbein MRICS, is the Henri B. Meier Professor of Financial Management at the University of Basel, Switzerland. Before joining faculty in Basel, he was with the Swiss Institute of Banking and Finance at the University of St. Gallen. Gantenbein has been a visiting professor at HEC Paris, the University of Geneva, the Wits Business School in Johannesburg, and HEC Montréal. His academic interests are in the areas of corporate finance, portfolio management, risk management, real estate finance, and venture finance. 